\title{
OBSERVATIONS ON A NEW CHLOROCOCCAL ALGA FROM TRANSYLVANIA
}

\author{
F. NAGY-TÓTH
}

Dept Plant Physiology, Babes-Bolyai University, 3400 Cluj-Napoca, Romania

(Received 1 May, 2000)

Ecdysichlamys transylvanica sp. nov. is described and its relations discussed based on microscopic observations and physiological analyses made on natural materials and laboratory static and batch cultures.

In laboratory conditions it develops typical feature in biphasic medium, however it grows well in other usual artificial media, too (e.g. Benecke, Witsch, Knop-Pringsheim, Knop-Pringsheim-Felföldy, Kuhl-Lorenzen), in which it reveals many characteristic morphoses (pleomorphism).

Key words: cell ultrastructure, chlorococcal alga, Ecdysichlamys transylvanica, microscopic features, pure culture, Transylvania

\section{INTRODUCTION}

Enrichment algal cultures display, most often, prodigious diversity of species and forms which delight the algologists and equally prove their skill and perseverance in identifying them. The dilemma resides partly in the essential differences between an alga living in natural habitats and its counterpart grown under laboratory conditions, and partly in the ambiguity of the taxonomic keys, which, as known, are mainly based on criteria occurring under natural life conditions. Moreover, in addition to the classical microscopic marks, biochemical, physiological, ontogenetic and ecological peculiarities nowadays are also required in order to better characterise the alga considered (Weier et al. 1970, Ettl and Popovsky 1986, Nagy-Tóth and Barna 1988, Hindák 1990, Trainor and Egan 1990). Needless to say that such a huge amount of data can be gathered only during long-term works.

An enrichment raw algal culture and its subsequent unialgal cultures have offered a lucky chance to observe, for years, an interesting Chlorococcal alga. The results recorded will be evaluated in this paper. 


\section{MATERIAL AND METHODS}

The alga herein dealt with was found in a subaerophytically grown blue-greenish crust scrapped off concrete blocks constantly showered by the stream of cooling water of the thermal power-station in Nagyvárad, close to the inflow into the Körös river. The water was clear, fast running, its $\mathrm{pH}$ ranged between $7.5-8$, the temperature in the periphyton was $16^{\circ} \mathrm{C}$, but in the air only $10{ }^{\circ} \mathrm{C}$, on the day of sampling (9 October, 1974).

Enrichment culture was initiated from the sample at very place in agarized Benecke's medium. The subsequent trial cultures were always developed simultaneously in four, also agarized media, i.e. two sorts of Benecke's (with $\mathrm{K}_{2} \mathrm{HPO}_{4}$ or $\mathrm{KH}_{2} \mathrm{PO}_{4}$ ), Knop-Pringsheim's and Witsch's media; about $40 \mathrm{ml}$ in 100-ml Erlenmeyer flasks. They were kept in glass cupboard at $20 \pm 2{ }^{\circ} \mathrm{C}$, in natural light (500-700 lux).

The earliest cultures and many of the subsequent ones were dominated by filamentous blue-green algae, mainly Spirulina- and Phormidiumlike. From one of such cultures Phormidium viscosum Lemm. was isolated, among other species, in unialgal pure culture and its behaviour was experimented in different artificial media (Fabian et al. 1981). Sometimes passing colonies of purple bacteria also appeared on the agar surface of the stock cultures. After a while, following several passages, at the beginning rare, brilliant green dots became more dense both on and in the agar of the media. In these colonies, especially in older cultures, peculiar "capped", singular, ellipsoidal cells were frequently found (Scenedesmus 'calotatus' ). They were observed more carefully and during a few passages we succeeded to isolate them in unialgal pure culture. The alga continued, of course, to be observed with growing interest, first of all in order to identify it taxonomically. During these observations it was drawn (with a Zeiss camera lucida attached to a Leitz photonomicroscope) in many stages of development and under different culture conditions (Plates I-VI).

The electron microscopic structure has been investigated in cells grown both in static run cultures in Knop-Pringsheim's solution and in intensive bubbled batch cultures using the same preparative procedures and BS 500 TESLA transmission electron microscope as in other studies (Péterfi et al. 1988).

Intensive bubbled semicontinuous cultures were performed in 3 sets of experiments. In the 1st set (2-10 July, 1981) this alga was grown comparatively with other 6 Transylvanian Chlorococcal algae in 5,000 lux ("Daylight" tubes of $40 \mathrm{~W}$ ) and at $20 \pm 2{ }^{\circ} \mathrm{C}$ (Plate III, Figs 1-6); in the 2nd set (1-7 
September, 1981) the light intensity was 6,500+200 lux, the temperature $22 \pm 2{ }^{\circ} \mathrm{C}$ (Plate III, Figs 7-11), while in the 3rd set (10-19 November, 1987) the light intensities were increased stepwise from 6,500+200 lux to $9,500+800$ lux, the temperature being $24 \pm 2{ }^{\circ} \mathrm{C}$ (Plate III, Figs 21-28) and up to $11,000+1100$ lux, the temperature was kept at $34 \pm 2{ }^{\circ} \mathrm{C}$ (Plate III, Figs 29-33). In all the 3 sets of experiments the same Kuhl-Lorenzen's nutrient solution (Kuhl and Lorenzen 1964) and the modified Vladimirova-Semenenko's vessels (Nagy-Tóth 1972) were used. The vessels containing the initial algal suspensions were attached to the device which assured sterile growth conditions (Péterfi and Nagy-Tóth 1967).

The cell biomass harvested at the end of the log growth phase were analysed for soluble protein, lipid and pigment contents (Nagy-Tóth et al. 1980) and based on cell and optical densities as well as on the amount of dry matter, growth rate and productivity were calculated (Stein 1973).

\section{RESULTS AND DISCUSSION}

\section{Light microscopical observations (Plates I-VI)}

Cell pairs adjoined flat-sided and opposite-ended are typical for this alga. This is the feature which captures, above all, the attention. Nevertheless, in laboratory pure culture the single cell stages are overwhelming and in this status it can resemble many Chlorococcal algal species. Colonies or groups of 4 cells are rare, and those encased in hyaline spherical mucilage are more scarce.

Generally, the shape of cells is originally ovoid, hence heteropolar (bipolar) and asymmetric since one side is flat, but never convex, due to the diagonally slipped position inside the mother cell. Later on, during development and ageing the cells can become ellipsoid and spindle-shaped or lemon-like, as well as many transition forms. Nevertheless, the two ends of the cell mostly differ, the broader rounded ones having always smaller pointed papilla, or mainly in younger stages lacking any emergence, while the narrower end has, at least, a visible emergence, but more frequently a pointed papilla or a circular thickening. Soon, regularly on this narrower end, and later on the other apex too, a wart-like bulge, calotte (skull cap) will emerge, whose surface can be granulated. This formation is the 2 nd peculiar characteristic of the alga studied. 


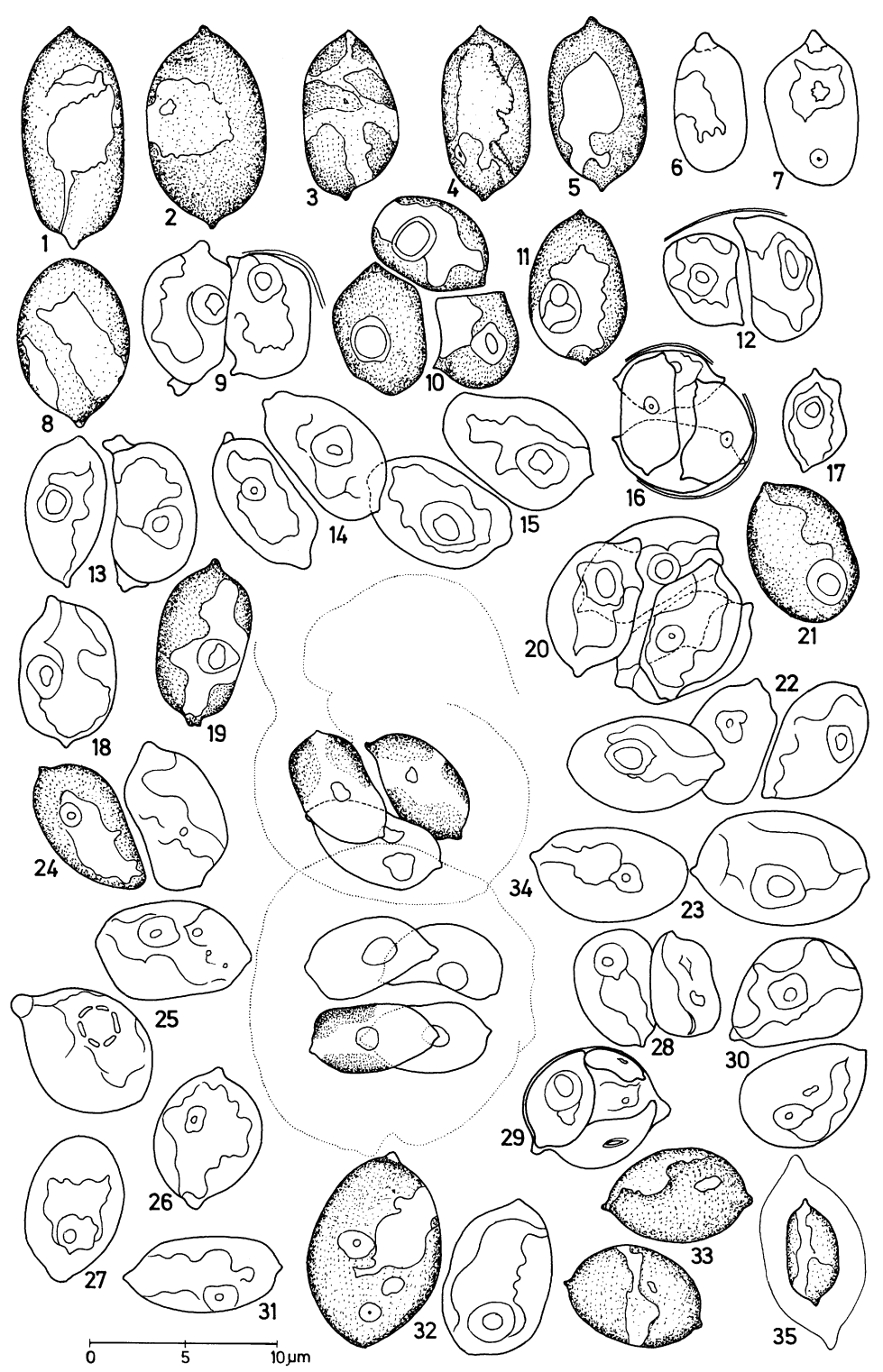

Plate I. Morphoses appeared in static run cultures grown in soil-water medium for 29 days (Figs 1-8), 50 days (Figs 33-35), 84 days (Figs 9-20) and for 109 days (Figs 21-32). Ellipsoidal single cells of variable sizes with pointed papillae on both apexes (Figs 1-5, 11, 17-19, 26, 31, 33 ), or with papilla and wart on one of the apexes (Figs 6-8, 21-23, 25, 27, 32). One-sided flattened ellipsoidal or ovoid, characteristically paired cells bearing warts or papillae on the apexes, and mother cell wall remnants (Figs 9, 12-15, 22, 24, 28, 30). Mother cell with forming and growing (Fig. 29), as well as with releasing autospores (Fig. 16), and groups of young cells (Figs 10, 20). Cells embedded in delicate mucilaginous matrix (Figs 34, 35) 


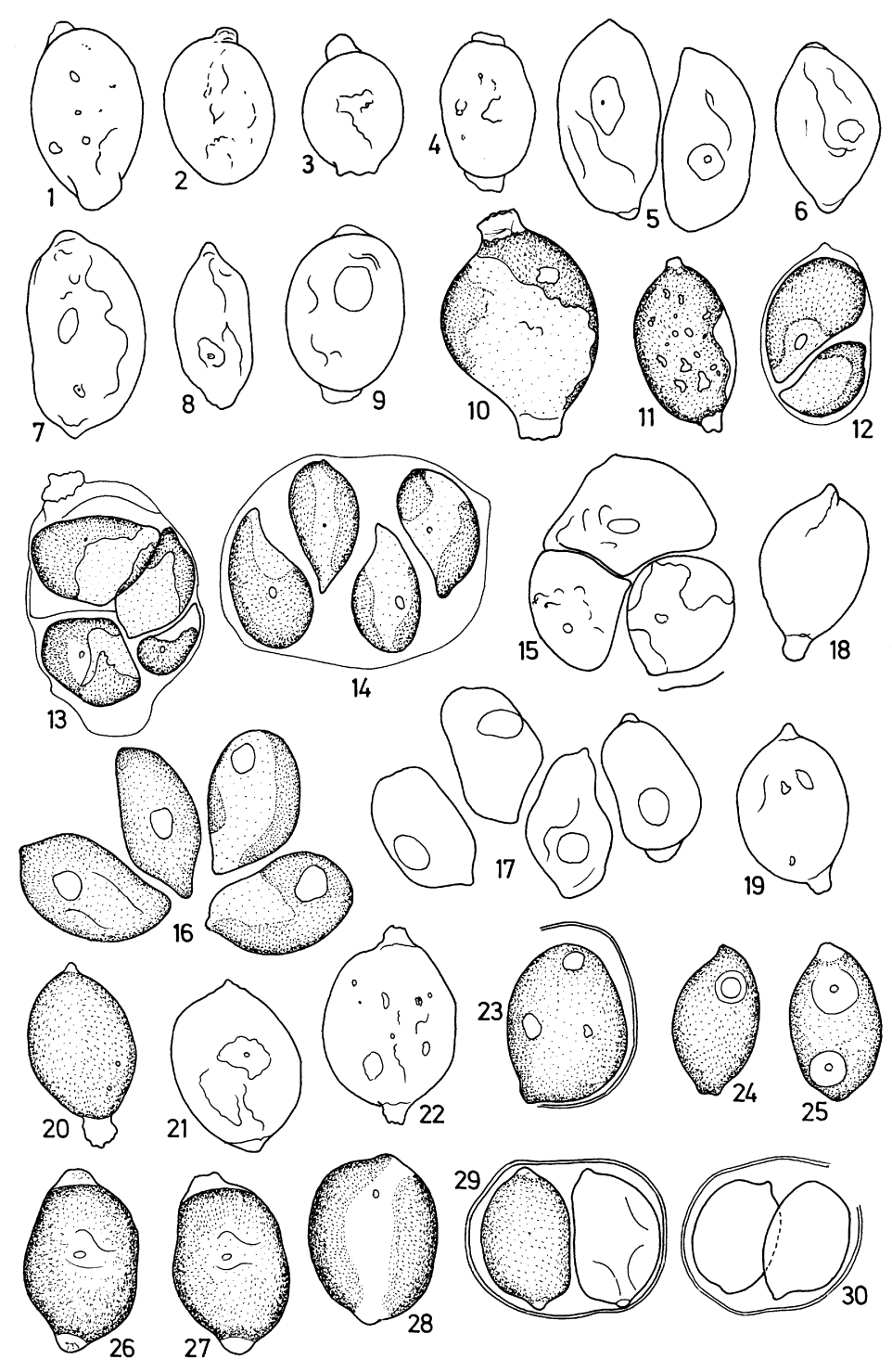

Plate II. Appearance of cells and colonies grown in static run cultures in Knop-Pringsheim's liquid nutrient solution for 200 (Figs 1-4), for 265 days (Figs 18-23), in Kuhl-Lorenzen's solutions for 77 days (Figs 5-8), for 156 days (Figs 9, 12, 14, 16-17) and in Knop-PringsheimFelföldy's solution for 243 days (Figs 24-30). Variable ellipsoidal single cells with short poles bearing characteristically evident wart-like thickenings on one (Figs 2-3,20-21) or on both apexes (Figs 1, 4-11, 18-19, 22, 26-27). Characteristically paired (Figs 12, 14), or randomly disposed (Fig. 13) autospores in the mother cells. Young cells not yet completely liberated from the mother cells (Figs 23, 29-30) or separated (Figs 5, 15-17), but remaining in their paired position 


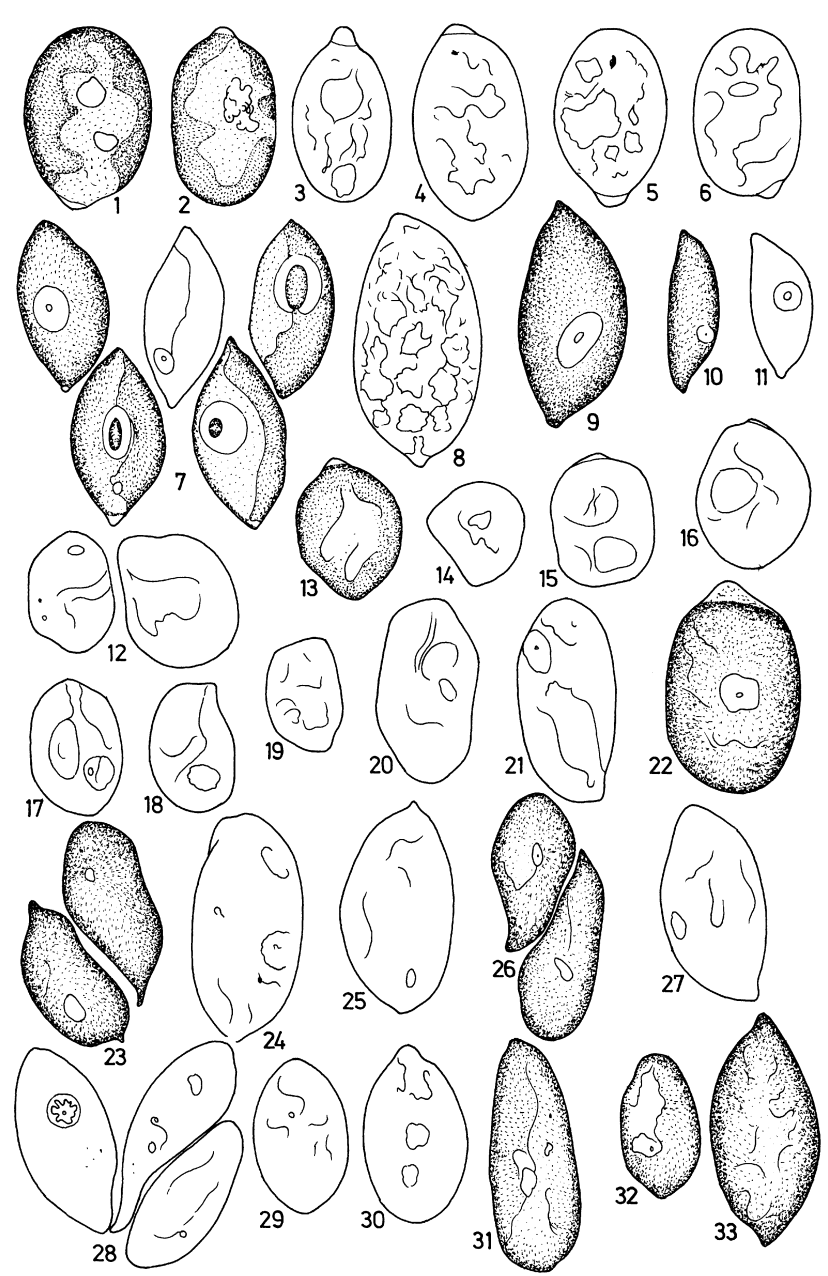

Plate III. Differences in cell shape and structure produced by culture conditions. Variable ellipsoidal and nearly spherical stocky cells with flattened wart-like, or tiny papillae on one of the apexes, or without any emergences arose in prolonged static run culture grown (for 200 days) on/in Benecke's agarized medium (Figs 12-20), from which the intensive bubbled batch cultures were initiated. Ellipsoidal and lemon-like cells with wart-like thickenings on one of the apexes developed in intensive batch culture (during 9 days) in Kuhl-Lorenzen's nutrient solution (Figs 1-6). Spindle-shape bipolar cells bearing delicate papillae on both apexes prevailed in a batch culture (of 7 days) in Kuhl-Lorenzen's nutrient solution, 6,500 lux and $22 \pm 2{ }^{\circ} \mathrm{C}$ (Figs 7-11). Elongated slender ellipsoidal and lagenaria-like (calabash-like) cells (Figs 23, 26, 28) and unipolar cells with or without papillae and thickenings were characteristic in a batch culture (of 10 days) grown in the same Kuhl-Lorenzen's nutrient solution, but at $9,500+800$ lux and $24 \pm 2{ }^{\circ} \mathrm{C}$ (Figs 21-28). Paired younger cells (Figs 23, 26, 28) also could be seen. Cells of somewhat similar ellipsoidal were formed in the parallel batch culture (of 10 days), likewise in Kuhl-Lorenzen's solution, but at $1100+1100$ lux and $34 \pm 2{ }^{\circ} \mathrm{C}$

(Figs 29-33) 


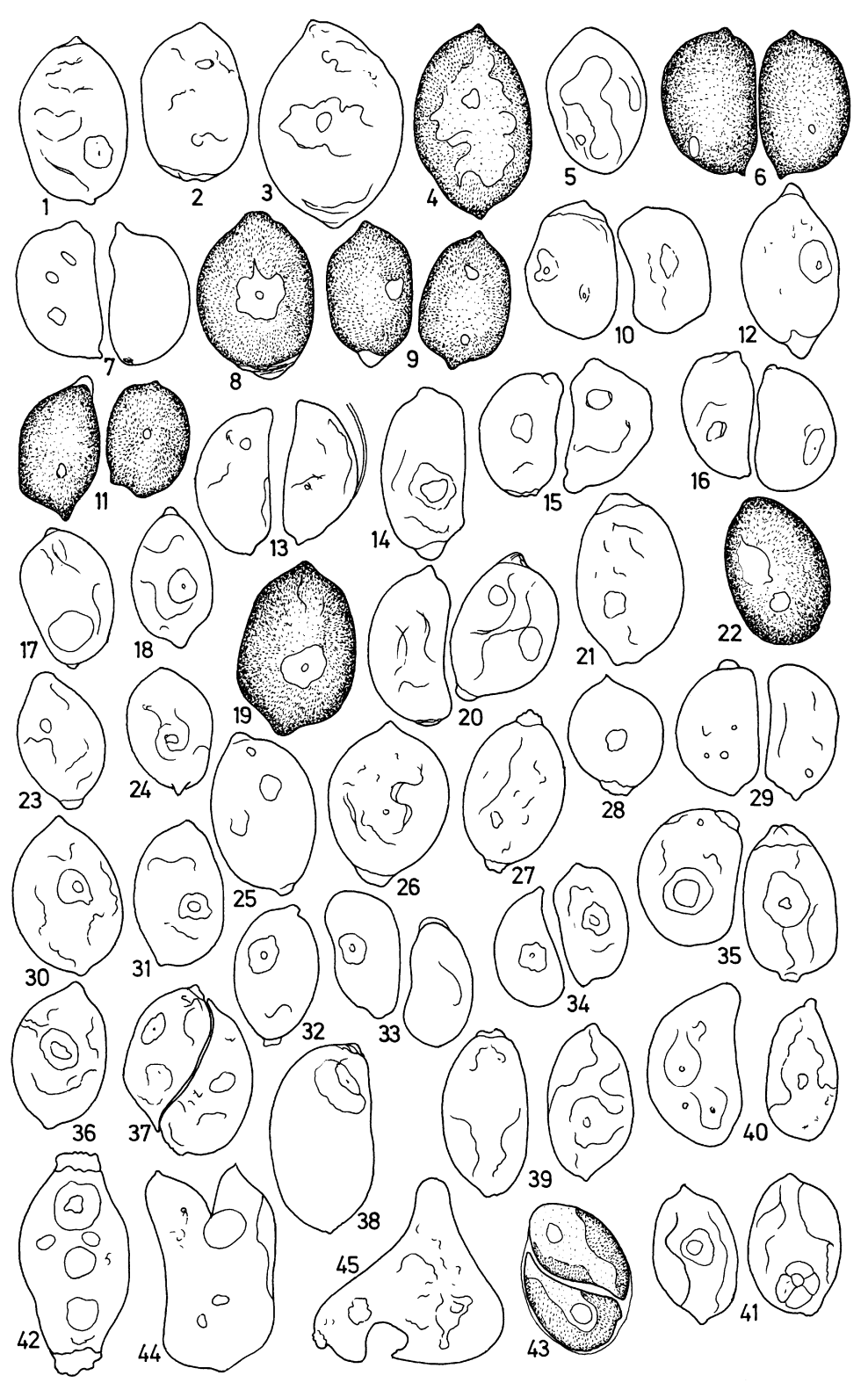

Plate IV. Variability of cell populations grown for 50 days (Figs 30-45), 200-230 days (Figs $1-5,10-29$ ) and for 450 days (Figs 6-9) in static run cultures on/in agarized Benecke's medium. Shorter, frequently irregular outlined, ovoid and lemon-like, stocky warted and papillated cells were overwhelming. However, more characteristic should be consider the paired cells which in this medium seems to be more frequent (Figs 6-7, 9-11, 13, 15-16, 20, 29, 33-35, 37) and also the autospore (Fig. 43). Remnant of mother cell wall (Fig. 13) and aberrant cells (Figs 44-45) can also be observed 


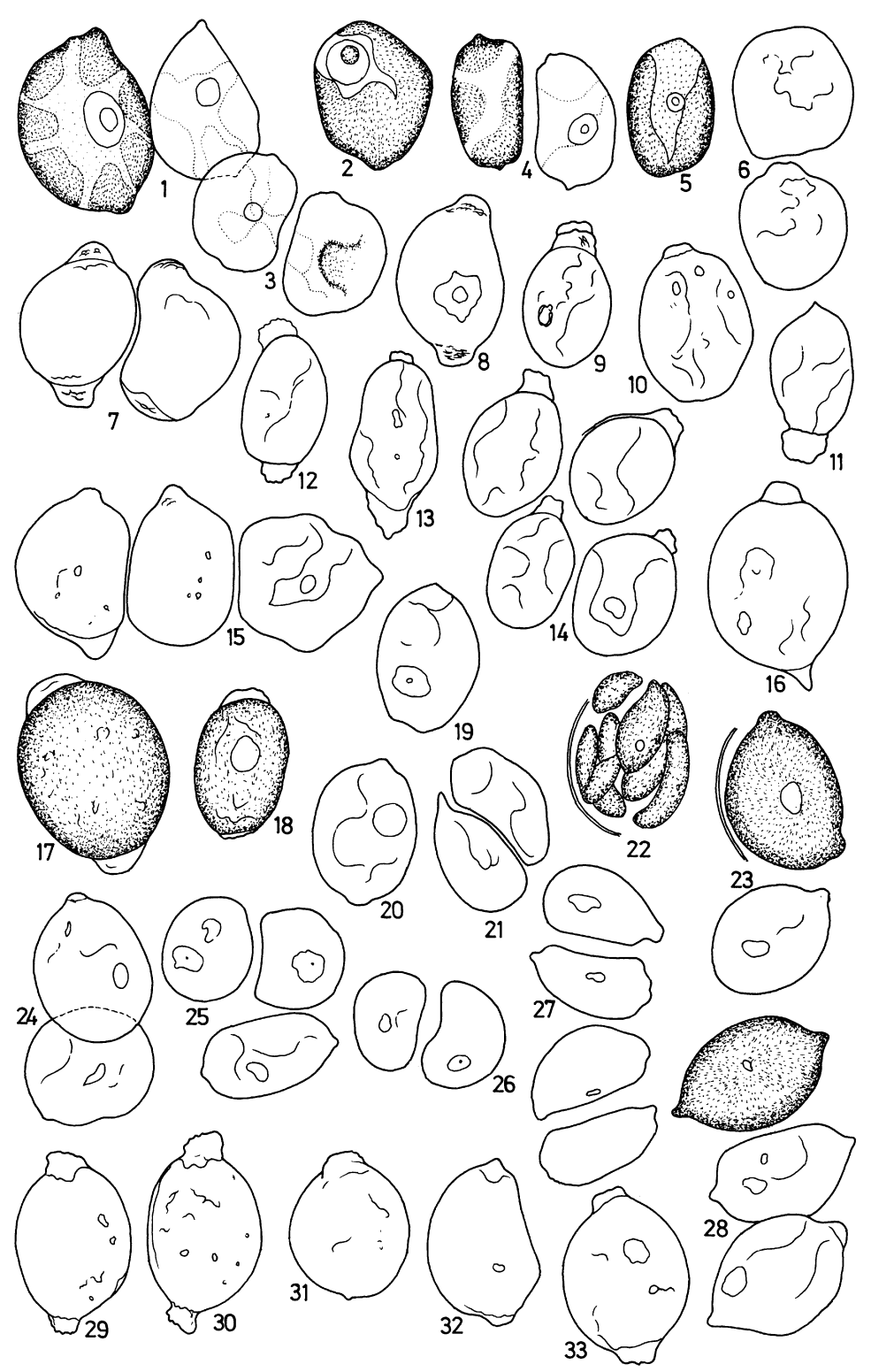

Plate $V$. The aspect of populations recorded in static run conditions in/on Knop-Pringsheim's agarized medium after 48 days (Figs 18-22), 265 days (Figs 29-30), 365 days (Figs 6-17, 23-28), 517 days (Figs 1-5) and after 704 days (Figs 31-33). Noticeable are the shorter ellipsoidal and lemon-like (Figs 9, 14, 16-20, 23-24, 28-30, 33), irregular outlined (Figs 2-8, 10-13, 15, 25, 32) strongly warted (Figs 7-13, 16-18, 29-33) cells. Cell pairs (Figs 4, 7, 21, 27), dividing cell (Fig. 1), autospore mother cell (Fig. 22) and cell wall remnants (Figs 22-23) were also present in these cultures 

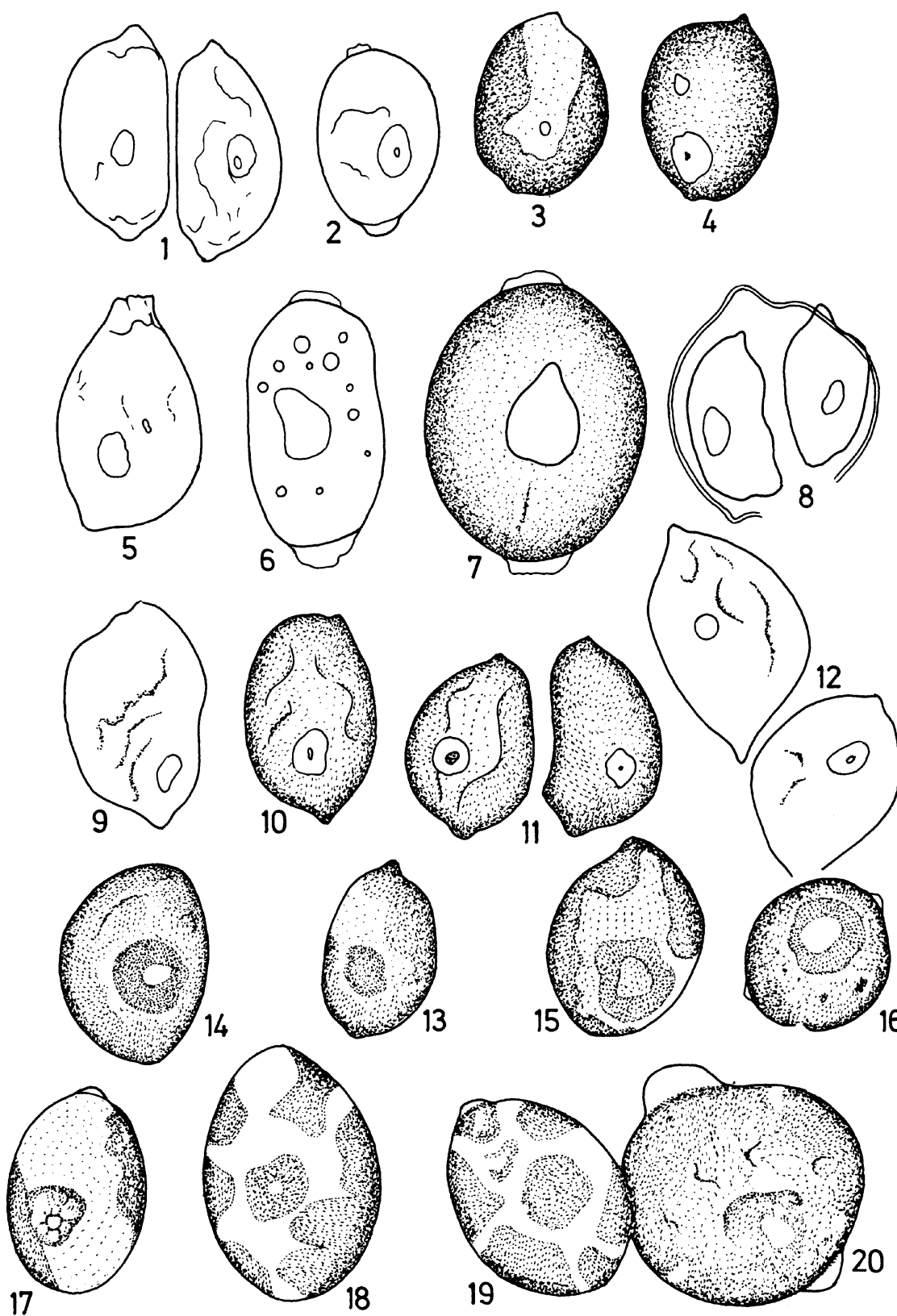

Plate VI. Variability of cells in static run cultures grown on/in agarized Witsch's medium for 48 days (Figs 1-2) and for 365 days (Figs 3-12). Stocky ellipsoidal and lemon-like evidently warted (Figs 2, 5-7), or papillated (Figs 1, 3-4, 9-12) cells prevailed, besides young cell pairs (Figs 1, 8, 11-12) were present. There were also cells in subsequent ontogenetic stages of growth (Figs 13-20) in refreshed soil-water medium 
The cell wall is hyaline, rather thin and smooth, without any ornamentation excepting, of course, the apical thickenings. Nearby young cells there are not infrequent cell wall remnants.

Chloroplast is only one in a cell. It is parietal, lining mostly the inside of cell wall. It is regularly trough shaped, with rounded, meekly winded or lobed, sometimes laced margin. Its surface appears smooth, but this aboriginal feature is subject to many changes; it can become wrinkled, granulated, perforated and slashed (even in a few pieces), with fringed margin. Its colour can vary from bright green, dark green to pale or yellowish green. It holds only one pyrenoid, which is large enough, and depending on life conditions can vary in size.

Cell sizes reached the limits of $5-13 \times 3-9 \mu \mathrm{m}$. The variation of cell dimensions never exceeded these values. So, in static run cultures there were recorded the following measures:

(a) soil-water (biphasic) medium: 5.25-12 × 3.50-7 $\mu \mathrm{m}$,

(b) Knop-Pringsheim's liquid medium: 6.50-11 × 3.50-6.75 $\mu \mathrm{m}$,

(c) Knop-Pringsheim-Felföldy's medium: 5.50-12 × 3.50-7.25 $\mu \mathrm{m}$,

(d) Knop-Pringsheim's agarized medium: 5-11 × 3.75-8.75 $\mu \mathrm{m}$,

(e) Benecke's agarized medium: 5.50-11.75 × 3.50-9 $\mu \mathrm{m}$,

(f) Witsch's agarized medium: 5.50-12 × 3.50-9 $\mu \mathrm{m}$

In intensive bubbled semicontinuous cultures in Kuhl-Lorenzen's nutrient solution: $7.50-13 \times 3.75-6.40 \mu \mathrm{m}$.

It can be seen that the mean values are fairly close, somewhat larger sizes occurring in intensive cultures. It seems that the cell sizes varies in a lesser degree than their shape (polymorphism).

The apical thickenings were of 0.5-1.5 $\mu \mathrm{m}$.

The alga multiplies by autospores; developing mostly 2 , and frequently 4 , rarely more daughter cells (under extreme life conditions).

\section{Electron microscopic characteristics}

The cell wall is two-layered, sometimes apparently doubled. The outer layer is electron dense, thin, albeit bilaminar and tough, due to its sporopollenin content; cross sections reveal many sporopollenin peeling off profiles originating from disrupting mother cell walls. The inner layer is a little thicker, lighter and granulated.

The chloroplast is extended, lining most of the inside of the cell wall, and is rather thick. Its extension and thickness vary depending on growth conditions and age. Young cells (especially autospores) chloroplast is more 
delicate, possessing fewer lamellae, while older ones and/or senescent chloroplast is more massive, unevenly thickened, sometimes perforated. The number of chloroplast lamellae varies too; there are fewer (about 5-7) in young cells, while in older ones it can reach 20 . In all cases the chloroplast lamellae run more or less parallel with the cell wall. They are mostly long and contain 3-7 thylakoids. Rarely, mainly in old cells, short thylakoid cysternae pile resembling grana, but real grana never occur. Interplastidial starch grains are usual and their number and size vary with the age and life conditions of the cells.

Chloroplasts have a single, fairly large, eccentric pyrenoid, which is coated by a two-half starch sheath (calotte). In some older cells the pyrenosome coating starch sheath is segmented, thus it is composed of a few plaques.

Outside the chloroplast, between its envelope and plasmalemma, there is a narrow streak of cytoplasm in which mitochondrial profiles and small vacuoles can be observed. The main body of the cytoplasm is, of course, in the centre of the cell, inside the chloroplast cavity. The other structural elements, common in Chlorococcal algal cells, and present in these sections are also located here. So, there is here a large nucleus with a single nucleolus, which takes up much of the cytoplasm volume. However, its position changes, usually being situated eccentric near the pyrenoid. In the proximity of the nucleus there are dictyosome consisting of a few Golgi cysternae.

The mitochondrial system is represented in the material examined as frequent profiles. Electron dense osmophilic globuli, apparently spongy, unknown composition (lipids?, polyphosphates?) are frequent in the cytoplasm.

As it might be expected, growth conditions affected profoundly the cell structure in this alga, too. Especially, chloroplasts revealed spectacular changes. Thus, while in the standard culture (static run in Knop-Pringsheim's solution, at $20 \pm 2{ }^{\circ} \mathrm{C}$, in 5,000 lux) they were fairly thick, possessing more thylakoids, being extended with lobed margin, those in batch, bubbled cultures (in Kuhl-Lorenzen's solution, at $34 \pm 2{ }^{\circ} \mathrm{C}$, in $11,000+1100$ lux) were much altered; viz. overloaded with starch grains, the thylakoids pushed aside from one another, thus the whole chloroplast became a characterless network. As a consequence its colour became pale green.

The pyrenosomes appear smaller, but their two-half starch sheath larger. The nucleus was most often pressed to the periphery of the cytoplasm. The surface of the wall appeared more waved (creneled is cross sec- 
tions). Maybe the over-optimal temperature and light intensity account for more than 2 or 4 autospores in a mother cell (since the nutrient solution and other factors were similar).

In moderately higher light intensity (6,500 lux) essential changes in cell structures of this alga did not occur. So, the chloroplast looked like those in standard grown cells. Nevertheless, the higher frequency of young cells and the peeling off sporopollenin stratum prove a higher division rate in this culture.

Comparing these cultures grown in higher light intensities one can conclude that the light is the principal factor which alters the structure of the chloroplast.

\section{Phycophysiological properties (Figs 1-2)}

(a) Growth and multiplication were sensitively influenced by temperature and light intensity. Starting with an initial density of 70 cells $/ \mu 1$ (equivalent to an optical extinction of $\mathrm{E}=0.005$ ) the intensive bubbled batch cultures grown exponentially during 10 days without reaching their stationary phase (Fig. 1). Cell densities at that time were 105,000 cells $/ \mu \mathrm{l}$ (equivalent to $\mathrm{E}=1.825)$ under thermo- and photophilic conditions $\left(34 \pm 2{ }^{\circ} \mathrm{C}\right.$, $11,000+1100 \mathrm{lux}$ ) and 51,000 cells $/ \mu \mathrm{l}$ (equivalent to $\mathrm{E}=0.825$ ) in mesophilic ones $\left(24 \pm 2{ }^{\circ} \mathrm{C}, 9,500+800 \mathrm{lux}\right)$. The growth rate, calculated from these data, was nearly 1 (i. e. 0.94 for the thermophilic and 0.78 for the mesophilic condition), which is fairly good, since even in Emerson's strain of Chlorella pyrenoidosa the value ranged between 0.90 and 0.93 (Fogg 1965). Of the 6 autochthonous Chlorococcal species cultivated parallel this alga reached the highest values (Fig. 2).

The excellent growth of the studied alga at higher temperature and more intense light is, perhaps, accounted for its ancestral thermophilic property, since it originates from thermally polluted water.

(b) Biomass production was, naturally, in agreement with growth and multiplication. The productivity attained under thermophilic condition was of $0.62 \mathrm{~g}$ dry matter/1/day, while under mesophilic ones only $0.33 \mathrm{~g}$ dry matter/1/day (nearly half). The higher productivity was a consequence not only of higher cell densities, but also of increased cell sizes.

(c) Biochemical composition of the cells differed significantly depending on temperature and light intensity. Soluble protein and pigment contents were inversely, while the lipid content was directly proportional with temperature and light intensities. Thus, under thermo- and photophilic 

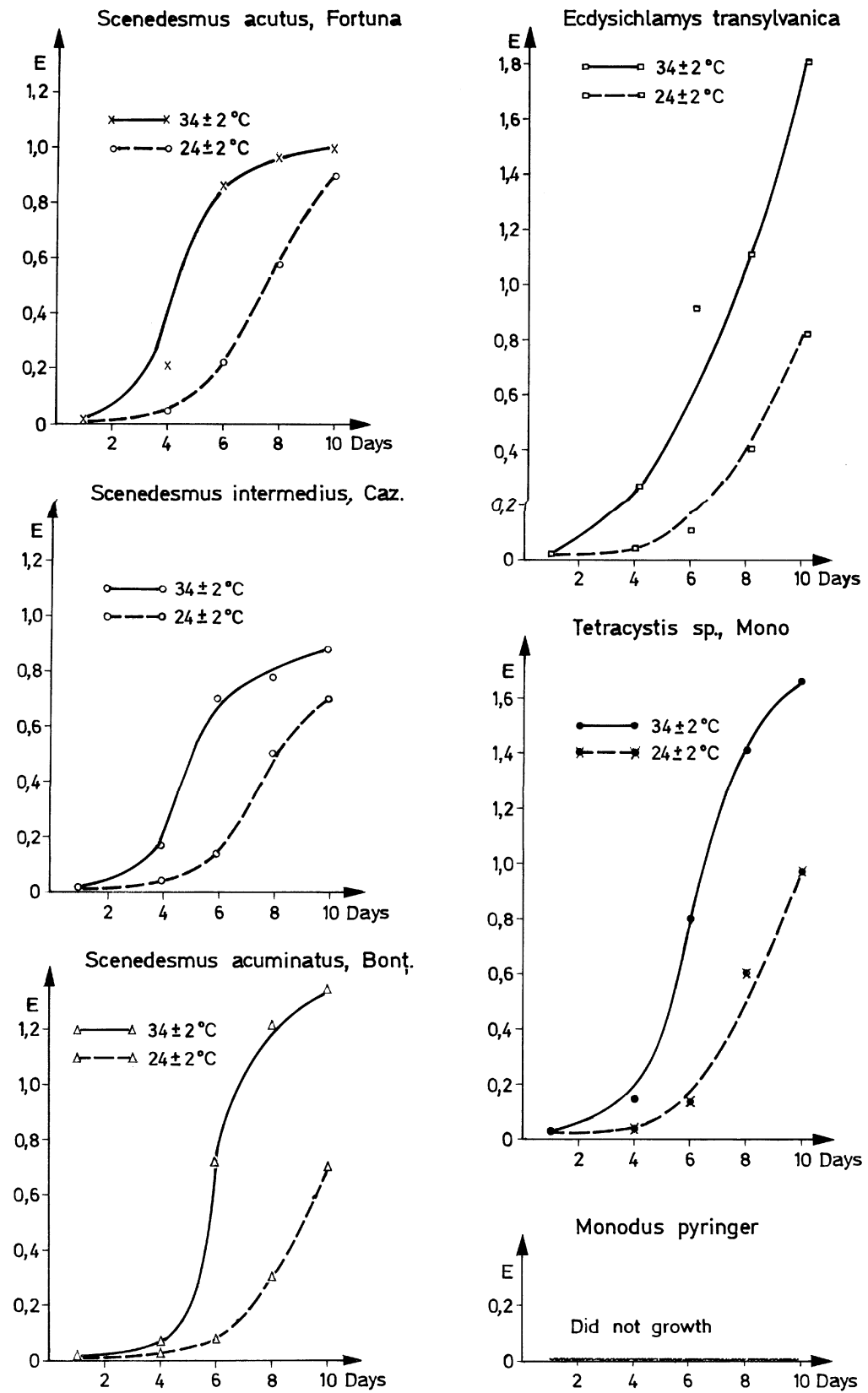

Fig. 1. The effect of temperature on the multiplication of Ecdisychlamys transylvanica and other 5 species grown in batch cultures; Kuhl-Lorenzen's nutrient solution, 9,500+800 lux, $24 \pm 2{ }^{\circ} \mathrm{C}$, and $11,000+1100 \operatorname{lux}, 34 \pm 2{ }^{\circ} \mathrm{C}$ 
conditions soluble proteins amounted to $6.33 \%$, in mesophilic ones to $9.40 \%$ (on dry weight basis); total pigments were $0.74 \%$, of which chlorophyll $a$ $0.40 \%$, chlorophyll $b \quad 0.18 \%$, carotenoids $0.16 \%$, while under mesophilic conditions the respective values were $1.35 \%$, of which $0.80 \%, 0.33 \%$ and $0.22 \%$. As it can be seen, if light intensity doubled, the pigment contents in the cells nearly the half. These values and variations are supported by many similar data published (e.g. Fogg et al. 1959, Böger 1964). The lipid content was $3.40 \%$ in the cells grown at higher, and $2.00 \%$ at lower temperature and light intensities. According to Becker and Venkataraman's data (1978) Scenedesmus species contain more lipids (12-19\%) than Chlorellas (10-15\%). On this basis the analysed alga would be closer to Chlorella species. However, the lipid content can vary between $4.5 \%$ and $85 \%$ (Milner 1961). Otherwise the higher lipid quantity under photo- and thermophilic conditions can be a consequence of faster growth due to which the exponential phase is reached sooner and in this status, according to Sidorova and Maximova (1985), the lipid content is higher.

\section{Taxonomic remarks and discussions}

During the experiments, which involved different developmental stages, many observations were recorded and the alga was tentatively compared with various Chlorococcal species. At the beginning, due to its shape in single cell stage and peculiar apical cap-like thickenings (calotte), chloroplast and pyrenoid conformation, it was named, funnily, Scenedesmus 'calotatus'.

Indeed, the cells (especially in older culture) resemble some of Scenedesmus species. So, it was thought to be a new form of Scenedesmus acutus Meyen var. globosus Hortob. (Uherkovich 1966). Furthermore, it was related to S. dactylococcopsis Chod. (Chodat 1926, Uherkovich 1966), especially by the diagonally slipped position of the autospores inside mother cells. Based on the characteristic wart-like apical thickenings it was also compared with Steinedesmus ralfsii (Playf.) Comas et Komárek (syn. Scenedesmus ralfsii Playf.), especially with a form found in Cuba (Comas and Komárek 1985). However, the alga herewith discussed cannot be identified with Steinedesmus, which otherwise is questioned by Hegewald et al. (1988), either by coenobium or by cell shape and size. The lack of the typical four- or more-celled coenobia in any circumstances, and the frequency of the characteristically paired heteropolar asymmetric cells place this alga in a peculiar position among the Chlorococcal species. 
Other algae to which the present form was related more stubbornly were a few Oocystis species; especially when the apical wart-like thickenings, the cell shape and the presence, though not always, of the expanded mother cell walls were considered. So, it appeared fairly close to the Oocystis solitaria Wittr., particularly to a form given by Hindák (1988), which in its younger stage of development can possess only one chloroplast as this alga. Similarly, it resembled Oocystis parva West et G. S. West, as well as to O. lacustris Chod. drawn by Rehakova (1969). Nevertheless, there are es-

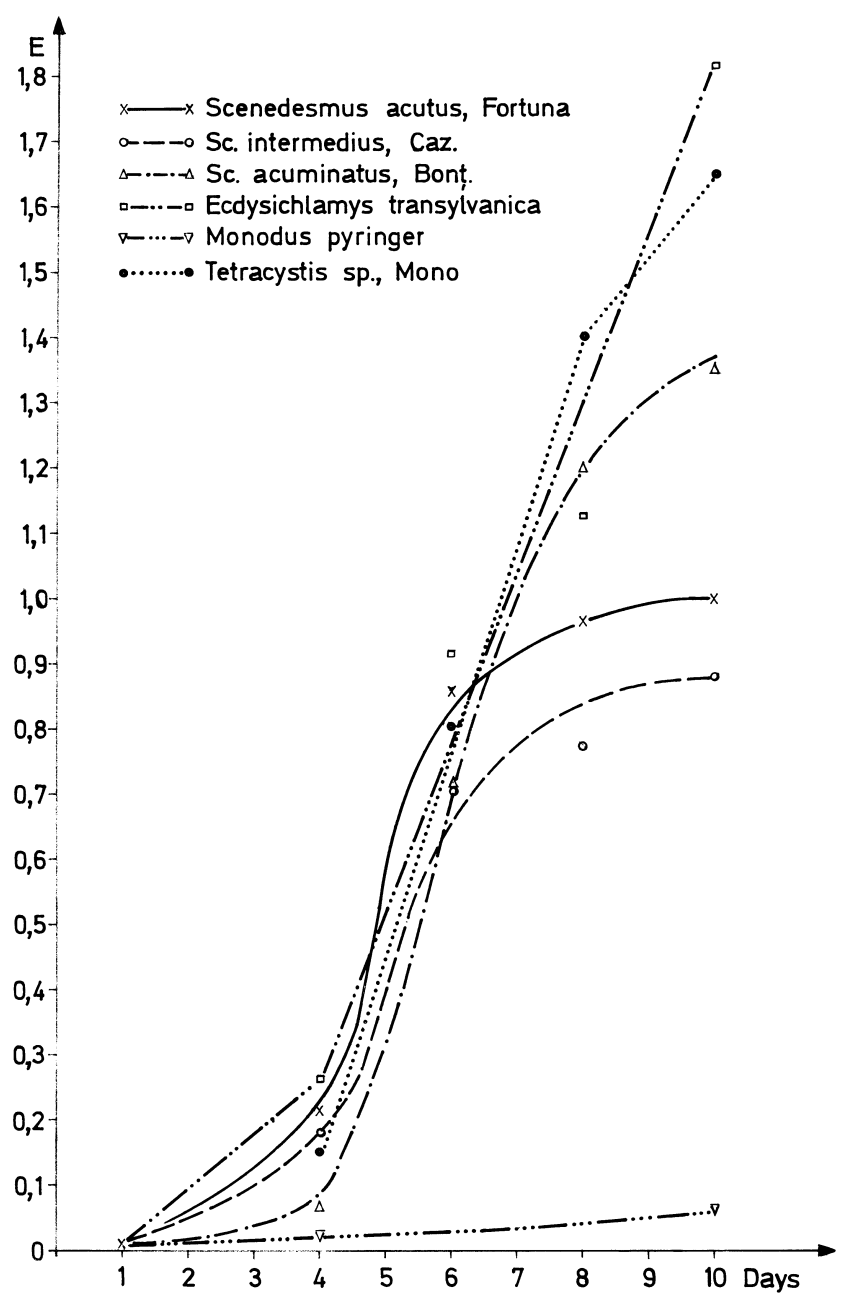

Fig. 2. Comparison of the multiplication potential of 6 Transylvanian algal species in intensive batch cultures; Kuhl-Lorenzen's solution, 6,500+200 lux, $22 \pm 2{ }^{\circ} \mathrm{C}$ 
sential differences mainly in respect of chloroplast number (which in Oocystis usually is more than one), and the way of autospore liberation. Finally, Oocystis alpina Reisigl was the taxon to which our alga was related more reasonably.

Oocystis alpina was discovered by Reisigl (1964) in three soil samples collected in the Austrian Alps over than 3,000 m above the sea level. Interestingly, it was not considered either by Rehalova (1969) or by Hindák (1988). It was included in Komárek and Fott's monograph (1983), albeit without any complementary data or comments ("Die Arten noch weitere taxonomische oder nomenclatorische Bearbeitung benötingen").

In a later study Komárek and Comas (1984) transferred Oocystis alpina to the genus Ecdysichlamys. But neither was this new study completed with more details on Ecdysichlamys (Oocystis ) alpina (Reisigl) Komárek et Comas. Otherwise, it seems interesting to mention that Bourelly (1966) did not recognise this genus and assigned it to Oocystis ("le genre Ecdysichlamys G. S. West est un Oocystis de forme irregulière").

Actually, the studied alga is not identical with Reisigl's species. It has aboriginally a different shape, thinner cell wall, other form of apical thickening, chloroplast and pyrenoid, and completely different ecology. Yet among the Ecdysichlamys species there is an ecomorph of E. obliqua G.S. West found in Cuba, which by its habitat ("grew subaerophytically making a layer over the effluent tube from mineral springs and over the surrounding stones") and even by its accompanying algae (e.g. Phormidium) (Komárek and Comas 1984) could be related to our form. But our alga is smaller, its original shape is ovoid though asymmetric, the cell wall thinner, the apical wart-like thickenings stronger, generally the whole cell appears more delicate. Therefore, it cannot be included either in E. alpina (Reisigl) Komárek et Comas or in E. obliqua G. S. West. Consequently, I would propose to consider this alga a new species and name it Ecdysichlamys transylvanica.

\section{Ecdysichlamys transylvanica spec. nova}

\footnotetext{
Diagnosis: Algae aspectu typica cum paribus cellulis plano-lateribus atque apice opposite conjunctis. Cellulis solitaribus frequentibus atque in statu initiale accretionis in colonias quadricellulares dispositis, rariter in massa mucilaginea sphaerica inclusae.

Cellularum forma aboriginalis ovales, accrementi tempore ellipsoidalis, citriformis vel fusiformis esse potest. Semper asymmetrica. Earum pars extrema in latitudine ac in crassitudine differt. Pars angustior semper acuta atque papillata, postea manifeste verrucosa, nonnunquam in superficie granulata, quae est algae characteristica specialis.
} 
Earum dimensiones: 5-13 × 3-9 $\mu \mathrm{m}$.

Cellulae paries hyalinus, potius tenellus, sed firmus, sporopolleninam continens, raro a cellulis juvenilibus distantis. Chloroplastum unum, alveoliforme, statis tenue atque extensa, parietale dispositum, marginibus lobatis, cum pyrenoida unica quae binis granulas hemisphaericas amylli habet.

Multiplicatio per 2 (4-8) paribus conjunctis autosporibus quae per parietis cellulae matricariae ruptionem liberavit.

Occurentia subaerophytica supra saxos humidos, in canalis thermo-polluatis, in associatione cum algis filamentosis cyaneis. Probalitier alga thermophila.

Lectotypus in Collectione Laboratorii Algologicae Universitatis Claudiopitannae reperitur.

Typical appearance of the alga with cell pairs flat-sided and opposite-ended adjoined; solitary cells frequent and in earlier stage of development colonies of 4 cells encased in spherical mucilage rare. Cell shape originally ovoid, which during growth might became ellipsoid, lemon- or spindle-like, always asymmetric. Cell ends differ in breadth and thickening. The narrower end always pointed papillated; later evidently warted (sometimes granulated on the surface), which is a peculiar feature of this alga. Dimensions: 5-13 × 3-9 $\mu \mathrm{m}$. Cell wall hyaline, rather thin, but tough (firm) containing sporopollenin. Rarely widened from the young cells. Chloroplast one, trough-shaped, rather thick and extended, parietal with lobed margin, holds one pyrenoid with two-half starch sheath. Multiplication by 2 (4-8) autospores paired-associated in mother cells, which are liberated by the rupture of the mother cell wall.

Occurrence subaerophytically on wet stones in thermally polluted water stream, associated with filamentous blue-green algae. Probably thermophilic.

\section{REFERENCES}

Becker, E. W. and Venkataraman, L. V. (1978): A manual on the cultivation and processing of Algae as a source of single cell protein. - Central Food technological Research Institute, Myosure (India), pp. 1-45.

Bourelly, P. (1964): Les Algues d'Eau Duce. I. - Ed. Boubeé et Cie, Paris, pp. 159-188, 208-231.

Böger, P. (1964): Das Strukturproteid aus Chloroplasten einzelliger Grünalgen und seine Beziehung zum Chlorophyll. - Flora 154: 174-211.

Chodat, R. (1926): Scenedesmus. Étude de Génétique, de Systématique et d'Hydrobiologie. - Rev. Hydrobiol. 3: 71-258.

Comas, A. and Komárek, J. (1985): The genus Steinedesmus Kofoid (Scenedesmaceae, Chlorellales). - Preslia (Praha) 57: 97-110.

Ettl, H. and Popovsky, J. (1986): Current problems in the taxonomy of algae. - Arch. Hydrobiol. Suppl. 73: 1-20. 
Fabian, A., Nagy-Tóth, F., Barna, A. and Rácz-Bélteky, E. (1981): About the morphological and physiological characteristics of the blue-green alga Phormidium viscosum Lemm. - Rev. Roum. Biol., Ser. Biol. Veget. 26: 133-140.

Fogg, G. E. (1965): Algal culture and phytoplankton ecology. - Athlone Press, London, pp. 11-32.

Fogg, G. E., Smith, W. E. E. and Miller, I. D. A. (1959): An apparatus for the culture of algae under controlled conditions. - J. Biochem. Microbiol. Technol. Eng. 1: 59-76.

Hegewald, E., Engelberg, K. E. and Paschma, R. (1988): Beitrag zur Taxonomie der Gattung Scenedesmus Subgenus Scenedesmus (Chlorophyceae). - Nova Hedwigia 47: 497-533.

Hindák, F. (1988): Studies on Chlorococcal algae (Chlorophyceae). IV. - Publ. Slovak Acad. Sci., Bratislava, pp. 102-165.

Hindák, F. (1990): Studies on Chlorococcal algae (Chlorophyceae). V. - Publ. Slovak Acad. Sci., Bratislava, pp. 5-225.

Komárek, J. and Comas, A. (1984): The genus Ecdysichlamys (Chlorellales). - Preslia (Praha) 56: $13-28$.

Komárek, J. and Fott., B. (1983): Das Phytoplankton des Süsswassers. - E. Schweizerbart'sche Verlagsbuchhandlung, Stuttgart, pp. 484-487.

Kuhl, A. and Lorenzen, H. (1964): Handling and culturing of Chlorella. - In: Prescott, D. M. (ed.): Methods in cell physiology. I. Acad. Press, New York, pp. 159-187.

Milner, H. W. (1961): The chemical compositions of algae. - In: Burlew, J. S. (ed.): Algal culture from laboratory to pilot plant. Carnegie Inst. Washington, Washington, D.C., pp. 285-302.

Nagy-Tóth, F. (1972): Cercetări privitoare la cultivarea intensivă a unor alge verzi. - Dr. Thesis, Univ. Cluj, Cluj, pp. 5-33.

Nagy-Tóth, F. and Barna, A. (1988): Preocupări recente în algologie. - Studia Univ. BabesBolyai, Ser. Biol. 33: 7-20.

Nagy-Tóth, F., Barcea, V., Barna, A. and Stirban, M. (1980): The dynamics of photosynthetic pigments and the productivity of some Scenedesmus species. - Rev. Roum. Biol., Ser. Biol. Veget. 25: 21-43.

Péterfi, L. S., Momeu, L., Nagy-Tóth, F. and Crăcium, V. (1988): Observations on the fine structure of Chlorococcum minutum Starr (Chlorococcales, Chlorophyceae). Vegetative cells and zoospores. - Arch. Protistenkd. 135: 133-145.

Péterfi, S. and Nagy-Tóth, F. (1967): Untersuchungen über Massenkulturen von Süsswasseralgen. - Rev. Roum. Biol., Ser. Bot. 12: 199-206.

Rehakova, H. (1969): Die Variabilität der Arten der Gattung Oocystis A. Braun. - Studies in Phycology, Publ. Czechoslovak. Acad. Sci., Praha, pp. 145-197.

Reisigl, H. (1964): Zur Systematik und Ökologie alpiner Bodenalgen. - Österr. Bot. Zeitschr. 111: 403-499.

Sidorova, O. A. and Maximova, I. V. (1985): Lipidy zelenoi vodorosli Westella botryoides i ikh svetozavivisimaya antibakterial'naya aktivnost. - Fiziol. Rast. (Moskva) 32: 465-472.

Stein, J. R. (1973): Handbook of physiological methods. - Cambridge Univ Press, Cambridge, pp. 289-358.

Trainor, F. R. and Egan, P. F. (1990): Discovering the various ecomorphs of Scenedesmus: the end of a taxonomic era. - In: Hindák, F. (ed.): Biology and taxonomy of green algae. Internat. Symp. Smolenice (Czecho-Slovakia), June 25-29, 1990, Bratislava, p. 65.

Uherkovich, G. (1966): Die Scenedesmus-Arten Ungarns. - Verl. Akad., Budapest, pp. 36-41.

Weier, T. E., Stocking, C. R. and Barbour, M. G. (1970): Botany. - J. Wiley and Sons, New York, pp. 441-479. 